\title{
Comparing Criteria: Assessing the Significance of Memorials
}

\author{
LISA MURRAY
}

\footnotetext{
Commemoration is a practice that shapes collective memory: how we remember, what we remember and what we forget. The erection of a memorial as a commemorative gesture is often a deliberate attempt by a section of the community places their understandings of an event, policy or person in the public domain and into the historical record. In this sense the aim of a memorial is to create a heritage site or place. ${ }^{1}$

Cemeteries are outdoor museums and many are of great heritage significance. They gain their heritage significance from a combination of values. Partly it is the collection of memorials and the collective commemorative functions that summarise a local community. But the memorials themselves form just one aspect of the cemetery's commemorative landscape. The layout, plantings, setting and vistas are also important elements of a cemetery's value as a commemorative landscape.
}

\author{
Public History Review \\ No 15 (2008): 135-52 \\ (c) UTSePress and the author
}


Memorials are often raised by public subscription or supported by government grants and are meant to represent broad community values. Some are raised by individuals or private groups and are more personal in intent. Memorials usually address two audiences: the private memories of those intimately associated with the memorialised activity or person and the historical consciousness and collective memory of the general public. The relative importance and/or dominance of these two types of memories can change over time and may be reflected the ceremonies and visitation levels associated with the memorial.

The concept of heritage as a form of identification by the community of sites, places and objects that hold special values and should be preserved from the ravages of time or development emerged in Australia in the 1960s and was formulated into a legislative structure in New South Wales with the passing of the NSW Heritage Act in 1977. Graeme Davison points out that 'heritage is essentially a political idea' that privileges the collective above the individual. ${ }^{2}$ It claims a collective interest - by the local community, the wider public, even the nation - in things that are often considered private. Heritage is not based on or defined by ownership or economic values, but rather shared values of cultural significance. And these shared values impart a sense of identity and ownership. But how are these shared values defined? And whose heritage is it?

That a place or object is valued by parts of the community as a heritage item sometimes comes to light when that place is neglected or under threat. ${ }^{3}$ The need to care for heritage places for future generations usually triggers research into a site's significance. Before deciding how to care for a place, it is necessary to understand what makes it important. Why do we value and want to care for it? Assessment is often a first step to formally listing a place or object on a heritage register. Heritage listing is a legislative and community acknowledgement of a site's value and the need to protect and conserve it for future generations. Heritage listing may bring other benefits such as increased public interest, a sense of shared community ownership and responsibility and access to funding for conservation works.

\section{Heritage Criteria: THe BURRA Charter}

Australia International Council on Monuments and Sites (ICOMOS), the peak body of professionals working in heritage conservation, first 
developed guidelines for the conservation of cultural significance in 1979. ${ }^{4}$ The Australia ICOMOS Burra Charter, 1999 (Burra Charter) has been adopted across Australia to provide a common language for people caring for places of cultural significance. It defines the basic principles and procedures to be observed in the conservation of important places.

Central to the Burra Charter's approach is the philosophy that the place itself is important and no form of archival recording or documentation can replace the experience of the actual heritage place. Australia ICOMOS recognises that heritage places are integral to our historical understanding and sense of Australian identity:

Places of cultural significance enrich people's lives, often providing a deep and inspirational sense of connection to community and landscape, to the past and to lived experiences. They are historical records that are important as tangible expressions of Australian identity and experience. Places of cultural significance reflect the diversity of our communities, telling us about who we are and the past that has formed us and the Australian landscape. They are irreplaceable and precious. These places of cultural significance must be conserved for present and future generations. ${ }^{5}$

For Australia ICOMOS, cultural significance means aesthetic, historic, scientific, social or spiritual value for past, present or future generations. This current definition is an expansion on the original four: aesthetic, historic, scientific, and social. Cultural significance is 'embodied in the place itself, its fabric, setting, use, associations, meanings, records, related places and related objects. It is important to remember that places may have a range of values for different individuals or groups. ${ }^{6}$

The Guidelines to Cultural Significance have not been updated since the fifth value of cultural significance - spiritual value - has been adopted by Australia ICOMOS in 1999. ${ }^{7}$ However, Meredith Walker and Peter Marquis-Kyle provide the most recent explanations of all five values in The Illustrated Burra Charter: Good Practice for Heritage Places (2004) when discussing the application of the Burra Charter process. Aesthetic value covers 'aspects of sensory perception - sight, touch, sound, taste and smell - for which criteria can and 
should be stated. These criteria may include consideration of the form, scale, colour, texture, and material of the fabric; and the smells and sounds associated with the place and its use. In some jurisdictions aesthetic value also encompasses creative or technical achievement.' Historic value includes the 'history of aesthetics, science and society, and therefore underlies other values. A place may have historic value because it has influenced, or has been influenced by, an historic figure, event, phase or activity. It may be the site of an important event. For any place the significance will be greater where the evidence of the association or event survives at the place, or where the setting is substantially intact, than where it has been changed or evidence does not survive. However, some events or associations may be so important that the place retains significance regardless of subsequent treatment. ${ }^{\prime 8}$

Scientific value pertains to the importance of the data involved, on its rarity, quality or representativeness, and the potential to contribute further substantial information about the place itself or a type or class of place.' Social value addresses 'the qualities for which a place is associated with a community or cultural group and the social, political or other cultural meanings that the place signifies to the group.' Finally, spiritual value concerns 'the non-material qualities evoked by a place and for which it has traditional meaning in the spiritual belief system, knowledge, art and practices of a cultural group. It may derive from the intensity of aesthetic or social values and the physical qualities of the place that inspire an overwhelming spontaneous response in people, evoking or broadening their understanding and respect of life. ${ }^{\prime 9}$

The Burra Charter was revised in 1999 to reflect advances in conservation philosophy and practice. The Charter's previous emphasis on the material culture of heritage has been tempered and it now tries to encompass less tangible aspects of cultural significance 'including those embodied in the use of heritage places, associations with a place and the meanings that places have for people'. ${ }^{10}$ This is reflected in the expansion of social value into two values - social value and spiritual value. Prior to the 1999 revisions, social value was defined as embracing the qualities for which a place has become a focus of spiritual, political, national or other cultural sentiment to a majority or minority group ${ }^{\prime 11}{ }^{11}$ These less tangible aspects of cultural significance are important elements of a memorial's heritage. 
The Burra Charter encourages the continuation or reestablishment of these associations and meanings through interpretation, commemoration, and celebration. ${ }^{12}$ Interpretation is seen as an important element of the conservation process. Interpretation of a memorial should enhance understanding and enjoyments, and be culturally appropriate. ${ }^{13}$

\section{Heritage Criteria: NSW Heritage Branch}

Assessing heritage using the former NSW Heritage Office and now the NSW Department of Planning Heritage Branch's significance criteria is essential if you wish to apply for a memorial or cemetery to be listed on the State Heritage Register. ${ }^{14}$ These criteria are also generally used by local councils to assess their heritage. Devising a statement of heritage significance based upon the NSW Heritage Branch criteria will also improve the likelihood of funding support from the Heritage Council or other government agencies.

The Heritage Branch defined seven criteria for assessing an item's heritage significance. The item must meet one or more criteria for listing on the State Heritage Register:

Criterion (a) An item is important in the course, or pattern, of NSW's cultural or natural history; Criterion (b) An item has strong or special association with the life or works of a person, or group of persons, of importance in NSW's cultural or natural history; Criterion (c) An item is important in demonstrating aesthetic characteristics and/or a high degree of creative or technical achievement in NSW;

Criterion (d) An item has strong or special association with a particular community or cultural group in NSW for social, cultural or spiritual reasons;

Criterion (e) An item has potential to yield information that will contribute to an understanding of NSW's cultural or natural history;

Criterion (f) An item possesses uncommon, rare or endangered aspects of NSW's cultural or natural history; Criterion (g) An item is important in demonstrating the principal characteristics of a class of NSW's cultural or natural places; or cultural or natural environments. ${ }^{15}$ 


\section{Heritage Criteria: Cemeteries Committee Heritage Values}

The Burra Charter's Guidelines to Cultural Significance (1988) notes that while the classification of cultural significance into four key values is flexible and convenient, it is not the only appropriate system. ${ }^{16} \mathrm{In}$ practice a more precise set of categories for assessing cultural significance may be prepared to suit the place. This is what the National Trust Cemeteries Committee has done.

The National Trust Cemeteries Committee has been a vocal advocate of cemetery and memorial conservation for over twentyfive years. The Committee was initially formed in response to the many neglected late-Victorian cemeteries in the Sydney metropolitan area. As a first step towards saving these cemeteries, the Committee conducted a field survey of all cemeteries in the Sydney metropolitan area. After completing this, it decided there was a need to identify and document cemeteries across the state and the survey work was expanded.

The state-wide survey and assessment of burial grounds provides the National Trust with an overview of the range and types of cemeteries in NSW. No one else is doing this and the Cemeteries Committee has accumulated considerable knowledge about cemeteries and their significance. The Cemeteries Committee is able to make a more informed judgement of the relative significance and importance of sites and to provide expert advice on cemetery conservation.

In 1985 the Committee published their first guidelines to assessing the significance of cemeteries. Using the Burra Charter as its basis, the Committee developed seven significance criteria specifically tailored to cemeteries and memorials which could be used as a guide or checklist for assessing a cemetery's heritage values. These have now been expanded to ten values. The following is an explanation of the ten criteria and how they relate to cemeteries and civic memorials. ${ }^{17}$

The heritage values that are applied to cemeteries can be equally applied to individual memorials. But it is not enough to consider the structure alone. A memorial needs to be considered in its context of the landscape and the community - both historical and contemporary. While the commemorative function of the cemetery was established in the nineteenth century and drew on a much longer commemorative tradition of the burial of the dead in churches, the commemorative functions of individual memorials can be much 
more ambivalent and sometimes it takes a lot more historical research to understand the original intentions of the memorial and shifting meanings a memorial might have.

Cemeteries have historical values. The cemetery is an historic record of Australian society. The site and its headstones are material culture which documents the development and growth of a community. The inscriptions of memorials as a collection can provide demographic information and insight into a town's social history. Class, religious and social identity are defined through memorial design and inscriptions. A cemetery may be of historical significance because it records a specific event, such as a mining disaster, or because it contains the graves of one or more noted individuals. The associated archival and documentary records of a cemetery, such as the burial registers, trustees' minutes and plans also form an important part of the historic record. Civic memorials may commemorate a specific event or policy or person. The unveiling ceremony and those associated with the memorial's erection may in time gain heritage significance for the documentation of a shift in historical understandings.

Cemeteries also have social values. Many cemeteries hold a special significance for individuals or communities as a result of personal sentiment and / or attachment to those buried or commemorated. The ceremonies and services held at memorials, and levels of visitation, are a reflection of the social value of the place. Cemeteries can also have layers of meanings - with individual monuments having private meanings while the collection of memorials may have other social values to the wider community. Graves and monuments can become the focus of community attitudes and respect; for example, early pioneers' graves and war graves. These social values and meanings can change over time.

Cemeteries reflect the religious beliefs and customs of different sections of the community and demonstrate religious values. This may be evidenced in the layout of the cemetery, the symbolism on memorials, inscriptions, and ceremonies. The cemetery itself may also have significance for particular religious groups and also for individuals.

Seven other areas of heritage values have been identified. All funerary monuments record genealogical information. Some headstones provide further biographical information; personal history, cause of 
death, occupations. In the case of headstones predating Civil Registration in 1856, the cemetery may provide the only records of the early European settlers. The grouping of monuments together in cemeteries often indicates family connections. The gravestones and monuments constitute a unique set of artistic, creative and technical elements and for this reason alone warrant preservation. Many cemeteries reflect in their design and monuments styles the changing attitude of the community towards death and movements in architectural and artistic style and theory. In Australia monument design moved in the nineteenth century from simple Georgian style to Gothic memorials and Classical monuments. A cemetery may be significant because of the variety of monument styles, or the type of materials used, or the quality of craftsmanship. Cemeteries often contain examples of work by local artisans and manufacturers. Iron grave surrounds may be locally produced, and sometimes bear the name of the manufacturer or iron foundry. The skill of Australia's stonemasons and sculptors is apparent to all who are familiar with nineteenth century monuments scattered throughout most cemeteries. The work of some talented monumental masons is akin to that of an artist. They often signed their work and developed their own carving styles.

Cemeteries also bear important relationships to either built or natural settings. It may be a prominent feature of the landscape or located adjacent to a church. A cemetery could also be a significant element within a townscape. The setting of a civic memorial or cemetery may contribute to its sense of place and the religious and social meanings attached to a place. Landscape design is also central to a cemetery's heritage significance. The arrangement of burial areas, alignment of drives, paths, avenues of trees and massing of shrubs are significant in the design of cemeteries. It is also important to consider to what extent the landscape design is still evident. Botanical Elements including extant natural vegetation, evergreen trees, bulbs, roses and other original plantings contribute to the cemetery's visual and nostalgic quality as well as providing a valuable botanical collection resource. Many early burial grounds often contain a variety of plantings which are no longer evident elsewhere. Some cemeteries contain significant remnants of the original natural vegetation. Overall landscape quality is determined by the combined effect of setting, landscape design, and botanical elements. 
Natural plant associations may also provide life support elements sanctuaries - for native animal life. Even where no rare or threatened species are identified, a cemetery may contain a rare or particularly well-preserved example of the ecosystems originally present in the area. For this reason it is important to consider the plants as an association, not just a collection of types, and also to look at whether they attract birds or other fauna which add to the value of the cemetery to the community.

Lastly, human remains in a cemetery are not generally visible. But they comprise a major element of heritage significance. Reasons for their importance include archaeological and scientific potential, issues of religious belief, their meaning to relatives and general community respect for our ancestors. These issues remain relevant for unmarked graves and for burial areas cleared of previous monuments, as well as marked grave sites.

Once all of these values have been considered, then some comparative analysis is required. Comparative analysis should consider if an item is common or rare across a town, district, region or state. If the item is common, even ubiquitous, thought should be given as to whether the item is a particularly good example of its type. Things that may sway a decision that it is a representative example are that it is in better condition than most, that it has not been altered or that meanings and associations with the item are ongoing, demonstrating high social value. It is important to remember, too, that items might once have been common, but ongoing deterioration, obsolescence or removal now means that it is becoming rare.

\section{COMPARISON OF CRITERIA}

All memorials and cemeteries have some social and historic values and most have a greater or lesser degree of aesthetic values.

Cemeteries also have scientific value and the natural elements of a cemetery contribute some additional values, broadly referred to as existence value and life support value. Any one or more of these values may be important in assessing the heritage significance of a cemetery and all should be considered. So if you are going to assess a memorial's heritage significance, then the key question is which criteria should you use?

The table on pages 144-45 compares the National Trust's ten cemetery values with Heritage Branch criteria and the values 
identified in the Burra Charter to illustrate their relationship. Essentially, they cascade down in the order that has been discussed above, with the Burra Charter being the most generic, the Heritage Branch being a little more detailed and the National Trust's values being the most detailed. Both the Heritage Branch significance criteria and the National Trust cemetery heritage values encompass the five key values defined in the Burra Charter: historical, aesthetic, scientific, social and spiritual.

\section{Comparative Table OF Heritage VAlues}

\begin{tabular}{|c|c|c|}
\hline $\begin{array}{l}\text { National Trust } \\
\text { Cemetery Heritage } \\
\text { Values }\end{array}$ & NSW Heritage Branch criteria & $\begin{array}{l}\text { Burra } \\
\text { Charter }\end{array}$ \\
\hline Historical & $\begin{array}{l}\text { Criterion a: important in course or } \\
\text { pattern of history } \\
\text { Criterion b: historical associations with } \\
\text { people } \\
\text { Criterion e: potential to yield } \\
\text { information }\end{array}$ & Historic \\
\hline Social & $\begin{array}{l}\text { Criterion d: social, cultural or spiritual } \\
\text { associations for a group }\end{array}$ & $\begin{array}{l}\text { Social } \\
\text { Spiritual }\end{array}$ \\
\hline Religious & $\begin{array}{l}\text { Criterion d: social, cultural or spiritual } \\
\text { associations for a group } \\
\text { Criterion e: potential to yield } \\
\text { information }\end{array}$ & $\begin{array}{l}\text { Social } \\
\text { Spiritual }\end{array}$ \\
\hline Genealogical & $\begin{array}{l}\text { Criterion b: historical associations with } \\
\text { people } \\
\text { Criterion e: potential to yield } \\
\text { information } \\
\text { Criterion f: uncommon, rare or } \\
\text { endangered aspects }\end{array}$ & $\begin{array}{l}\text { Historic } \\
\text { Social }\end{array}$ \\
\hline $\begin{array}{l}\text { Artistic, Creative \& } \\
\text { Technical }\end{array}$ & $\begin{array}{l}\text { Criterion c: demonstrates aesthetic } \\
\text { characteristics and / or creative or } \\
\text { technical achievement } \\
\text { Criterion e: potential to yield } \\
\text { information } \\
\text { Criterion f: uncommon, rare or } \\
\text { endangered aspects } \\
\text { Criterion g: representative of a class or } \\
\text { type }\end{array}$ & $\begin{array}{l}\text { Aesthetic } \\
\text { Scientific }\end{array}$ \\
\hline
\end{tabular}




\begin{tabular}{|c|c|c|}
\hline $\begin{array}{l}\text { National Trust } \\
\text { Cemetery Heritage } \\
\text { Values }\end{array}$ & NSW Heritage Branch criteria & $\begin{array}{l}\text { Burra } \\
\text { Charter }\end{array}$ \\
\hline Setting & $\begin{array}{l}\text { Criterion a: important in course or } \\
\text { pattern of history } \\
\text { Criterion c: demonstrates aesthetic } \\
\text { characteristics and / or creative or } \\
\text { technical achievement } \\
\text { Criterion g: representative of a class or } \\
\text { type }\end{array}$ & $\begin{array}{l}\text { Aesthetic } \\
\text { Spiritual }\end{array}$ \\
\hline Landscape Design & $\begin{array}{l}\text { Criterion c: demonstrates aesthetic } \\
\text { Characteristics and / or creative or } \\
\text { technical achievement } \\
\text { Criterion f: uncommon, rare or } \\
\text { endangered aspects } \\
\text { Criterion g: representative of a class or } \\
\text { type }\end{array}$ & Aesthetic \\
\hline Botanical & $\begin{array}{l}\text { Criterion d: social, cultural or spiritual } \\
\text { associations for a group } \\
\text { Criterion e: potential to yield } \\
\text { information } \\
\text { Criterion f: uncommon, rare or } \\
\text { endangered aspects }\end{array}$ & $\begin{array}{l}\text { Aesthetic } \\
\text { Scientific }\end{array}$ \\
\hline Life Support & $\begin{array}{l}\text { Criterion d: social, cultural or spiritual } \\
\text { associations for a group } \\
\text { Criterion e: potential to yield } \\
\text { information } \\
\text { Criterion f: uncommon, rare or } \\
\text { endangered aspects }\end{array}$ & Scientific \\
\hline Human Remains & $\begin{array}{l}\text { Criterion d: social, cultural or spiritual } \\
\text { associations for a group } \\
\text { Criterion e: potential to yield } \\
\text { information }\end{array}$ & $\begin{array}{l}\text { Scientific } \\
\text { Social } \\
\text { Spiritual }\end{array}$ \\
\hline
\end{tabular}

The Heritage Branch explains that the 'generic' values of the Burra Charter have been expanded into their seven criteria to 'maintain consistency with the criteria of other Australian heritage agencies; minimise ambiguity during the assessment process; and avoid the legal misinterpretation of the completed assessment of listed items. ${ }^{\prime 18}$ The first five Heritage Branch criteria are roughly analogous to the values in the Burra Charter. Criteria $\mathrm{f}$ and $\mathrm{g}$ - rarity and representativeness - are comparative values that theoretically can be applied to any other heritage value. In the table, the most likely 
heritage values for listing cemeteries on these comparative bases have been identified.

Difficulties in using the Heritage Branch and Burra Charter criteria stem from the fact that they are broad and apply equally to houses, parks and cemeteries. For the uninitiated it can be difficult to apply to memorials. The Burra Charter has improved since its original introduction in 1979 by the addition of spiritual value. More importantly, Australia ICOMOS has recognised that an emphasis on the conservation of fabric has led many to assume that an item's chief heritage significance must lie in its material culture. In its revision in 1999 Australia ICOMOS attempted to broaden the community's understanding of cultural significance to encompass use, associations and meanings. Thus cultural significance 'is embodied in the place itself, its setting, use, associations, meanings, records, related places and related objects'. ${ }^{19}$

The Heritage Branch has also improved its heritage criteria through its emphasis on historical understandings of place, people and associations. Thus historic has been separated out into criteria a and $b$. Indeed the Heritage Branch - or at least the former NSW Heritage Office - believes that history underlies the whole heritage assessment process, through the relationship between and item and its historical context. ${ }^{20}$

The National Trust's list of ten heritage values goes one step further in that they have been specifically developed for cemeteries and can be readily applied to commemorative landscapes and civic memorials. They expand upon the criteria developed in the conservation charters allowing specific, detailed analysis of a site's natural and cultural heritage significance. The National Trust recommends that its ten heritage values for cemeteries be used as a checklist to ensure that all elements of a cemetery are considered when evaluating its heritage significance. These values can then be used as the basis for forming a statement of heritage significance according to the Heritage Branch criteria.

But are the current criteria adequate and do they capture all aspects of a memorial's significance? The comparison of items raises many problems. One area where the Heritage Branch criteria are inadequate for the assessment of memorials is in their levels of significance. Items can be either of local significance or state significance. Previously regional studies allowed for a third levelthat of regional significance - but this was abolished by the NSW 
Heritage Office 'to simply the assessment process' ${ }^{21}$ This is particularly frustrating for the assessment of cemeteries and memorials. Many memorials hold social value wider than a local community. Memorials associated with a district's industry, for example, would have regional significance. The Cemeteries Committee believes that regional significance still has relevance for the assessment of cemeteries and memorials, particularly war memorials.

The Heritage Branch suggests that wider historical themes can be helpful when trying to assess an item's significance across the state. But try applying historical themes to a war memorial and you begin to see difficulties. Many local war memorials are comparatively not that significant in their aesthetic values, being standard digger memorials ordered from a monumental mason. All war memorials are historically associated with an event in Australian history: a major world conflict. So how can you compare one memorial to another? What distinguishes a memorial?

This is where aspects of intangible significance come into play. It is important to consider what are the current and former uses of the memorial. This might bring to light opposition to the memorialisation process, or the fact that the memorial was in a different place or location. It might show that the memorial previously had a utilitarian function as a water fountain, but that the bubblers have since been removed and that it is now simply a monument. It might show that previously the memorial was only the focus for commemoration on Anzac Day but that now all the town's war commemorations are focussed on the memorial. The memorial might have taken on new functions and meanings, becoming a local landmark as a meeting spot in the centre of town, or the place from where all directions are given (the pub's just north of the memorial). The associations of a memorial with groups of people should be considered. What types of events or ceremonies have taken place at the memorial? Who has participated and who has been excluded from these ceremonies? Has the level of local interest and participation in these ceremonies changed over time?

One of the major inadequacies of current heritage legislation is the emphasis on the physical, tangible forms of memorialisation with an eye to permanency. Too often heritage criteria are skewed towards the built environment. Cynics would say that this is because 
politicians are more interested in things that can be restored, reused or unveiled. The heritage value of memorials are not simply embodied in the structure itself. The place, the memorial's specific location, setting and landscape design or qualities of the memorial's surrounds are often integral to the design and meaning of memorials. And their significance is shaped by the complex area of social memory. ${ }^{22}$

John Gillis has argued that the relationship between memory and identity is an historical construct that can be traced through the commemorative process. 'Commemorative activity', he contends, ' is by definition social and political, for it involves the coordination of individual and group memories, whose results may appear consensual when they are in fact the product of processes of intense contest, struggle, and in some instances, annihilation. ${ }^{23}$ One of the interesting aspects of a memorial that contributes to our understanding of cultural history is the story behind getting the memorial off the ground. Who first suggested the memorial and what were their intentions? From where did the funds to erect the memorial come? How was the design of the memorial settled upon? The process of memorialisation is frequently not well documented in the archives, and thus can sometimes be overlooked when the history of the memorial is being written. It is also often difficult to capture the significance of the memorialisation process in the statement of cultural significance. But it is often the negotiations that take place during the process of choosing and designing a memorial that reveal the most about cultural memory and the community.

Another shortcoming of all heritage criteria for the assessment of memorials is their inability to express the changing, ambivalent or contested meanings attached to memorials. It is covered under social value. But usually this value is taken to refer to contemporary meanings held by current communities. And as it is, heritage practitioners and the community alike have had trouble coming to terms with social value. ${ }^{24}$ I believe that the commemorative aspects and the subtleties of meanings can often be flattened by heritage assessment. Perhaps it is relevant to include another value in the National Trust's list - memory.

Memorials as a class, because of their commemorative function, inherently have some social values. ${ }^{25}$ Consequently an 'active' cemetery or 'contemporary' memorial could be considered to have heritage values. Memorials fund-raised by public subscription could 
be argued to have immediate social value due to their associations with a particular group who have shared values and meanings. Thus an important question arises: when does a memorial become 'heritage'?

The difficulty in listing contemporary buildings or memorials as heritage is the conundrum of time. ${ }^{26}$ Many people's base concept of heritage is old, rare or under threat. But much of our late twentiethcentury heritage is none of these. The antiquarian approach privileges age over other historic values. Does a memorial have to have been erected for a certain number of years - twenty years, fifty years - before it can be considered for listing? No heritage charter actually defines a set period before an item can be considered as heritage, and rightly so. If survival and age were the main criteria for all heritage listings - an unfortunate fate for some rare heritage items - then much would be ignored. The memorial's case is particularly fraught because it is a political act to overtly create historic meanings and identify shared associations and values. This ticks several heritage criteria. Given that the Burra Charter acknowledges that the cultural significance of an item can change over time as a result of the 'continuing history of the place', ${ }^{27}$ philosophically there is no argument against identifying a memorial as being of heritage significance immediately upon its erection. However, one suspects that there would be resistance amongst the heritage profession and the wider community to such a practice.

It is also important to consider whether heritage criteria exclude some forms of memorialisation by their criteria. It can sometimes be difficult to mount a listing on the basis of social value even though this is one of the key aspects of the memorial process. A lone grave on a private property in the central west missed out on its status as a heritage item even though it met several criteria. The grave was for an early worker on the property. It had been planted with irises which naturalised into the near vicinity. But it had never had a headstone or permanent gravemarker. The irises popped up every year, a seasonal reminder of mortality. The existence of the grave had been passed down from property owner to property owner. The current owner of the land had selected a large piece of bush rock to place on the grave and was considering putting a plaque on it too. But he just hadn't got around to it yet. It was, however, rejected for a National Trust listing. Why? Ostensibly because it was 'unmarked' 
and there was not a lot of historical information. Yet it had a grave planting that readily identified the grave's location. Clearly the current owner attached some social and historical value to this grave. Did it matter that we didn't know the worker's name? Wasn't this grave evocative of the hardships of early rural workers, so often marginalised in the history of settlement? Doesn't the choice of irises as a gravemarker speak poignantly of burial practices in an isolated rural area where access to more formal forms of memorials may have been physically or economically difficult?

In the late twentieth century, there has been a greater move towards more ephemeral and participatory forms of commemoration: flowers at scenes of traumatic violence or deaths, roadside memorials. The internet has also seen the emergence of cybercemeteries and virtual memorials. The democratisation of commemorative process has raised some important issues for consideration. If they aren't permanent are these commemorative gestures actually memorials and could they be considered as holding any heritage significance?

A memorial is often a substantial plaque or structure monument, building, landscape - that is designed as a permanent, indelible form of commemoration. The desire for permanency is mitigated when a memorial becomes decayed and neglected. In such cases, does the neglect reflect changing social values? Does placing a memorial on a heritage list in a way acknowledge that it has lost some of its social value and its meanings need to be explained and protected? It is tempting to ask whether the act of heritage listing is a form of memorialisation in itself. Is the public fetish for plaques and interpretation merely acknowledgement that a place is forgotten or dead? Supporters of interpretation would argue that plaquing is a form of education, a means of explaining the past and the item's significance. But in the case of memorials, does that mean that the memorial hasn't done its job? Or has it done its job perfectly: is the commemorative process a self-fulfilling prophecy, externalising the memory so it can be forgotten?

This discursive comparison of heritage values as applied to memorials has raised more questions than provided answers. All memorials have some historic and social value, so perhaps the concept of memorials as heritage is a moot point. While any of the criteria can be applied to memorials, it is clear that the identification of more specific values is particularly useful when evaluating the 
heritage significance of a particular class or type such as memorials. Thus the criteria developed by the National Trust Cemeteries Committee are the most useful heritage criteria amongst those considered by this article. Nevertheless, none of the criteria are particularly good at capturing the memorial process and contested memories that are often attached to memorials. This reflects a wider problem with the definition of cultural significance in privileging material culture or fabric, a problem which Australia ICOMOS is trying to address by introducing the concept of intangible heritage.

\section{ENDNOTES}

${ }^{1}$ See for example, Lisa Murray, 'Cemeteries in nineteenth-century New South Wales: landscapes of memory and identity', PhD thesis, Department of History, University of Sydney, 2002.

${ }^{2}$ Graeme Davison, The Use and Abuse of Australian History, Allen \& Unwin, Sydney, 2000, p121.

3 ibid, p146.

${ }^{4}$ With the adoption of the 1999 revisions, the previous (1988) version of the Charter has now been superseded and joins the 1981 and 1979 versions as archival documents recording the development of conservation philosophy in Australia.

${ }^{5}$ Australia ICOMOS, The Burra Charter: The Australia ICOMOS Charter for Places of Cultural Significance 1999, Australia ICOMOS, Deakin University, Burwood, 2000, Preamble, p1.

${ }^{6}$ The Burra Charter 1999, Article 1.2.

${ }^{7}$ Australia ICOMOS, Guidelines to the Burra Charter: Cultural Significance, 1988, in The Burra Charter 1999, p11-13. These guidelines are still circulated with the revised Burra Charter and are still considered appropriate contextual documents.

${ }^{8}$ Meredith Walker and Peter Marquis-Kyle, The Illustrated Burra Charter: Good Practice for Heritage Places, Australia ICOMOS, Deakin University, Burwood, 2004, p80.

${ }^{9}$ ibid.

${ }^{10}$ Australia ICOMOS Secretariat, nd, Background to the Burra Charter, (Online). Available: http://www.icomos.org/australia/burracharter.html (Accessed 31 March 2008).

${ }^{11}$ Guidelines to the Burra Charter: Cultural Significance, 1988, 2.5.

${ }^{12}$ Burra Charter 1999, Article 24.

${ }^{13}$ Burra Charter 1999, Article 25.

${ }^{14}$ The NSW Heritage Office was closed and its functions transferred to the NSW Department of Planning in April 2008 under Minister Frank Sartor. See http://www/environment.gov.au/heritage/ organisations/state/nsw.ht ml (Accessed: 24 September 2008).

${ }^{15}$ NSW Heritage Office, NSW Heritage Manual: Assessing heritage significance, NSW Heritage Office, July 2001, p9.

${ }^{16}$ Guidelines to the Burra Charter: Cultural Significance, 1988, 2.6. 
${ }^{17}$ National Trust of Australia (NSW), nd, The value and significance of cemeteries, section 5, in Guidelines for Cemetery Conservation (Online). Available: http://www.nsw.nationaltrust.org.au/cemsvalue.html (Accessed: 31 March 2008).

${ }^{18}$ NSW Heritage Office, op cit, p8.

${ }^{19}$ Burra Charter 1999, Article 1.2.

${ }^{20}$ NSW Heritage Office, op cit, p5.

${ }^{21}$ ibid, p8.

${ }^{22}$ See, for example, Paula Hamilton and Linda Shopes (eds), Oral History and Public Memories, Temple University Press, Philadelphia, 2008.

${ }^{23}$ John R. Gillis, 'Memory and Identity: The History of a Relationship', in John R. Gillis (ed), Commemorations: The Politics of National Identity, Princeton University Press, Princeton, 1994, p5.

${ }^{24}$ See, for example, Chris Johnston, What Is Social Value?, Technical Publications Series no 3, Australian Heritage Commission, Canberra, 1992.

${ }^{25}$ National Trust (NSW), Cemeteries Policy Paper; Johnston, op cit, p10.

${ }^{26}$ Fran Stropin and Susan Marsden (eds), Twentieth-Century Heritage: marking the recent past, Australian Heritage Information Network, Adelaide, 2001, p41.

${ }^{27}$ Burra Charter 1999, Article 1.2 Explanatory Notes. 